a comenzar a leer sus arquitecturas, desentrañando la apariencia absoluta de sus formas, a comprender la belleza desigual de su estética, pero sobre todo a establecer un diálogo, tendiendo un puente entre pasado y presente. Entonces, los espacios ya transformados de aquella Málaga de la Edad Moderna habían cambiado, iniciando un camino, primero difícil porque no se entendían los fragmentos de una arquitectura maltrecha y una ornamentación herida de la que apenas podíamos ver algo y de modo parcial; en los años siguientes llegaron las restauraciones que sacaron a la luz el color y la forma de estas fachadas asentando las bases de su imagen renovada, y en los últimos años, este código de signos comenzó a entenderse como un recurso y potencial turístico cultural, hasta tal punto de pergeñar un itinerario para el deleite y conocimiento de sus usuarios. Hace unos días hablaba con ella de las últimas intervenciones en torno a este patrimonio, yo le comentaba sobre la actuación en calle Carretería, y ella me contaba unas fotos que le habían enviado de la Gerencia de Urbanismo, y quedamos para trabajar. Su compromiso con la investigación y la ciudad sigue intacto.

Hoy paseo por la Málaga de las arquitecturas pintadas, pienso en todo lo que hemos caminado, y no puedo evitar que gran parte de esa recuperación se la debemos a Rosario Camacho Martínez. Gracias por estar a disposición de Málaga, y por haber contribuido a comprender un poco más la diversidad de su legado cultural.

\title{
Rosario Camacho: editora y maestra ejemplar
}

\author{
Belén Calderón Roca \\ Universidad de Málaga
}

Las reseñas que integran este homenaje a la profesora Rosario Camacho Martínez pretenden ser una modesta contribución, destinada a elogiar su trayectoria en la faceta de editora de publicaciones desde la óptica de una discípula, con su más sincero afecto. Rosario Camacho reúne los méritos necesarios para ser considerada una personalidad protagonista de la Historia del Arte española del siglo XX, aunque quizás a nivel humano los que la conocemos bien, no podamos evitar mencionar su cercanía, su generosidad y su constante ofrecimiento de afecto y amistad. Rosario proyecta en todo mo- 
mento, consciente o inconscientemente, su sabiduría y su calidad humana en cualquier actividad profesional que emprende. El éxito de las múltiples publicaciones sobre temática patrimonial de las que se ha hecho cargo, ponen de manifiesto su condición de profunda conocedora de la historia del arte local. Inmensamente comprometida con la conservación de la memoria de Málaga, su principal pretensión ha sido adherirse a cualquier actividad que condujese a mantener viva la llama del propio sentimiento de apego a su ciudad y a la necesidad de compartir conocimientos sobre la misma. Su trayectoria vital, académica y profesional es una prueba de ello, pues no resulta extraño encontrar antiguos alumnos procedentes de diferentes generaciones que veneran sus enseñanzas y que intentan imitarla en lo profesional, algo muy difícil de conseguir. Para Rosario, su trabajo fue siempre su afición, algo con lo que continúa disfrutando enormemente y a lo que no le importa dedicar innumerables horas, muchas de ellas compartidas con quien escribe estas líneas.

Desde el Inventario artístico de Málaga y su provincia (1985); la Guía histórico-artística de Málaga (1992 y 2006), pasando por la Guía artística de Málaga y su provincia (2006) hasta la reciente Historia del Arte de Málaga (2011) son numerosas las publicaciones dirigidas, editadas y coordinadas por Rosario Camacho. No obstante, deseamos mencionar en estas páginas algunas en las que hemos participado, como es el libro Speculum sine macula. Santa María de la Victoria, espejo histórico de la ciudad de Málaga, editado por el Ayuntamiento y Hermandad de Santa María de la Victoria en 2008. Un largo proyecto de más de dos años de duración, que desde sus orígenes se concibió como un reflejo escrito de la propia historia y devoción profesadas por la ciudad de Málaga a su Patrona. La obra fue coordinada y dirigida por la profesora Camacho y los trabajos fueron encomendados a diferentes profesionales de la ciudad, destacados investigadores y profesores universitarios, así como a personas vinculadas y comprometidas con la Hermandad. El libro se divide en dos bloques bien diferenciados, estando el primero dedicado al análisis histórico de Santa María de la Victoria y a la Hermandad con relación a sus orígenes, su vinculación con la ciudad y su Consistorio, así como sus relaciones con la Diócesis. En el segundo bloque se introduce al lector en el conocimiento del acervo patrimonial tanto material como intangible vinculado a la Virgen de la Victoria y su Santuario, así como a la comunidad de fieles malagueños que le profesan culto y devoción.

Otros ejemplos a citar son las publicaciones derivadas de las conclusiones de cursos o congresos, como es el caso del libro Las ciudades históricas del Mediterráneo: el sector turístico, 
la dinamización cultural y las nuevas tecnologías aplicadas al Patrimonio Cultural. Esta obra fue editada y coordinada por Rosario Camacho y el profesor Eduardo Asenjo, fruto del curso celebrado en 2006 en la Universidad de Málaga, inserto en el proyecto de la Unión Europea «Euromed Heritage II: Patrimoines Partagés: Savoirs et savoirfaire apliques au patrimoine architectural et urbain des XIX-XX siècles en Méditerranée», experiencia que supuso la inauguración de una nueva línea de docencia de la Universidad de Málaga desde las coordenadas del Patrimonio y el Turismo. Este libro busca fomentar la necesidad del trabajo interdisciplinar y el rigor científico, así como el incremento de la capacidad de manejo de fuentes de información y el fomento de la capacidad crítica y valorativa respecto al patrimonio construido de las ciudades en nuestro entorno mediterráneo. Una acertada estructura aproxima al lector a la realidad de la ciudad histórica, integrando la teoría y la praxis más actual a través de diversos módulos: Las ciudades históricas del Mediterráneo: análisis de sus valores patrimoniales desde una mirada interdisciplinar; La intervención en el Patrimonio construido, como agente dinamizador para la recuperación de las ciudades históricas; El sector turístico y la oferta cultural en España: Realidades y problemáticas; Otras formas de conocimiento del Patrimonio Cultural en las ciudades históri- cas y Las nuevas tecnologías aplicadas al Patrimonio Cultural en las ciudades históricas. Dicha iniciativa quedó vinculada al área de Humanidades con solución de continuidad, manifestada un año después con el siguiente curso y publicación: Las ciudades históricas del Mediterráneo: Fuentes literarias y representación gráfica. Del Mundo antiguo a la Edad Contemporánea, libro que fue coeditado nuevamente en 2008 por Rosario Camacho y Eduardo Asenjo. La obra presenta un hilo argumental que gira en torno al estudio de la ciudad a través del tiempo, ofreciendo interesantes aportaciones sobre la repercusión de su imagen en la historia; acerca de la relevancia de sus arquitecturas más representativas y ofreciendo una lectura de la ciudad a través del análisis de imágenes, planimetría, documentos, tratados, grabados, fotografías, etc.

Por otra parte y como resultado de las ponencias presentadas en el Congreso Internacional Creación artística y mecenazgo en el desarrollo cultural del Mediterráneo en la Edad Moderna, surgido en el marco del Proyecto de I+D+I Tradición e innovación. La recepción de los modelos italianos en la periferia mediterránea y su difusión. Andalucía durante la Edad Moderna (HAR 200912095), del Ministerio de Ciencia e Innovación (actual de Economía y Competitividad), con Rosario Camacho como investigadora principal, se publicó este libro en 2011 con mismo título y con un 
objetivo fundamental: ofrecer una actualización de los estudios sobre las relaciones entre España e Italia mediante el estudio del entorno cultural mediterráneo durante la Edad Moderna. A través de dos bloques: Linaje y promoción de las artes e Intercambios artísticos y culturales se tratan aspectos relacionados con el mecenazgo y su papel en la promoción de proyectos y creación artística. En esta publicación se dan cita trabajos sobre el papel de los diplomáticos; la presencia española en Roma; el coleccionismo y la formación humanística; la influencia de los modelos artísticos y arquitectónicos italianos y el viaje como vehículo de formación y admiración de la cultura italiana, entre otros. Una ingente labor de coordinación supuso la edición de este libro, que quedó compensada por la magnitud de los resultados obtenidos.

Enmarcado en otra acción complementaria del mismo Proyecto I+D+I antes citado, el libro Fiestas y mecenazgo en las relaciones culturales del Mediterráneo en la Edad Moderna, constituye otro ejemplo de coordinación de una obra plural y compleja, que integra un compendio de los trabajos expuestos en el Seminario Internacional con mismo título celebrado en la Universidad Málaga en 2012. Esta obra en la que participaron numerosos profesores de diferentes universidades españolas e italianas se concibió como un trabajo interdisciplinar que perseguía un obje- tivo prioritario: profundizar en los estudios sobre la correspondencia entre la cultura española y la italiana en diferentes áreas de conocimiento. Múltiples fueron los temas tratados, tales como aspectos netamente festivos; el espacio escénico; la arquitectura efímera; la emblemática o el mecenazgo.

Llevar a cabo la dirección de este tipo de publicaciones resulta una tarea ardua y laboriosa que exige una elevada dedicación, actualizando trabajos y abriendo nuevas vías de investigación, además de coordinar a los diferentes autores con exquisito cuidado, evitando caer en la monotonía o en discursos repetitivos. La entrega de Rosario Camacho siempre ha ido más allá de su estricto cometido, y a su profesionalidad se une un exceso de celo en la búsqueda de la perfección y una responsabilidad mayúscula en este tipo de empresas que, en ocasiones, resultaron pesadas, pero que constituyeron un permanente aprendizaje y compensaron al contemplar el trabajo bien hecho. Deseo concluir estas reseñas de algunos momentos de la producción editorial de Rosario Camacho manifestando que he tenido el privilegio de colaborar en estas obras, tanto a nivel técnico en algunas, como coautora y coeditora en otras, y durante los largos meses de duro trabajo que ocupó cada preparación, he de decir que la satisfacción de aprender de una maestra ejemplar constituyó la mejor recompensa. 